\title{
Prophets Facing Sidewise: The Geopolitics of Knowledge and the Colonial Difference
}

\author{
Walter D. Mignolo
}

There is no safe place and no single locus of enunciation from where the uni-versal could be articulated for all and forever. H indu nationalism and Western neo-liberalism are entangled in a long history of thelogic of coloniality (domination, oppression, exploitation) hidden under the rhetoric of modernity (salvation, civilization, progress, development, freedom and democracy). There are, however, needs and possi bilities for I ndiansand W estern progressive intellectuals working together to undermine and supersede the assumptions that liberal thinkers in the W est are better placed to understand what is the common good better than Indian thinkers in post-partition India. Science, in the last analysis, doesn't carry in itself an ethics and politics. Therefore, it is doubtful to arguethat science is beyond both, and only concerned with the advancement of the frontier of knowledge and understanding. Science could be (like Christianity, Hinduism, Liberalism or M arxism) both imperial and liberating. Knowledge and understanding, rather than science; gnoseology rather than epistemology, should be thought out as which the horizon toward a dialogical and critical cosmopolitanism (e.g., pluriversallity as universal project), could be envisioned beyond East and W est, $\mathrm{H}$ indu nationalism and W estertn (neo) liberalism.

Keywords: Coloniality; Coloniality of knowledge; Border thinking; Abstract universals; Pluriversality as universal project; Critical cosmopolitanism

I.

Professor M eera Nanda's Prophets Facing Backward: Postmodern Critiques of Science and $\mathrm{H}$ indu $\mathrm{N}$ ationalism in India ${ }^{1}$ confronts a problem that, based on the history of India, is common to coloniality, the hidden side of modernity. The problem and the entanglement could be summarized as follows: the post-modern critique of science in Europe and in the U nited States ( from Feyerabend and Kuhn to the gender dimension in science and epistemology raised by Haraway, Harding, and Alcoff, among others)

Correspondenceto: Walter D. M ignolo, DukeU niversity, Institutefor Global Studies in Humanities, Department of Romance Studies, 224 Franklin Center, Durham, NC 27708-0413, USA. 
coincides with the critique of science, in India, enacted by Hindu nationalism. Therefore, what seems "progressive" within the local history of the "modern West" turns out to be straightforwardly conservative in the "traditional East" or non-W est. I am oversimplifying the argument for the need to be brief in this context. However, what I would like to emphasize is the "entanglement" between two (in this case) local histories, that of Euro-America's and that of India's modernity/coloniality. The foundation of the Atlantic world economy in thesixteenth century and of what would later become Western hegemony after the eighteenth century, has been grounded in the effectivelink between modernity and its darker side, coloniality. From the Euro-American perspective(and by that I mean a conceptual structure glued together by a system of beliefsthat allowed for the classification, ranking, and knowing of the world) the logic of coloniality is invisible as it is disguised by the lights of modernity's progressive mission. The rhetoric of modernity is based on a logic that is self-justified and self-satisfying; it is to deliver freedom and progress-salvation-to the rest of the world. But for that to happen someone has to suffer the consequences, and this is how the logic of coloniality has shaped the modern/colonial world.

What happens when you change the gaze and look not from the perspective of empire and the rhetoric of modernity but from the consequences of the logic of coloniality and the pain, suffering, devaluation, and exploitation of human beings? There are indeed many reactions, some critical, other extremist, and still other complacent. The complacent projects of the "native" promoters who want to "go modern" go hand-in-hand, in the structure of the modern/colonial world, with the "native" dissidents who want to "remain natives". Thus, while coloniality is the hidden logic covered up by the rhetoric of modernity, modernity is presented as the point of arrival of the colonial world, before and after independence. Independencechanged the actors but not the script. This chronological distinction (before and after independence) is irrelevant to the logic of coloniality that operates in different manners but doesn't go away as the constitutive companion of modernity. This is in a nutshell the crucial issue addressed by $\mathrm{N}$ anda by showing the complicities between postmodern critique of science in theW est, the Indian Left, and $\mathrm{H}$ indu Nationalism.

If theissues involved in the fact that colonial ity is constitutive of modernity aretoday of worldwide import and affect all spheres of life (from subjectivity to military interventionsand building of so-called W M D as a reaction to overpowering WDP (W eapons of Democratic Promotion; from political theory to political economy, from ethics and human rights to freetrade of drugs and human organs), $\mathrm{N}$ anda focuses on the question of knowledge and science and its political and ethical implications. And the implications are clear in Nanda's detailed, scholarly grounded and biographically motivated study. ${ }^{2}$ Which ones are they? These implications are articulated through the book, focusing on the Indian Left and Hindu Nationalism. Here is a paragraph in which $\mathrm{N}$ anda lays out the problematic positions adopted by the Left, through theexamination of some of Ashis N andy's (and associates') arguments:

$N$ andy and associates argued that because the Western philosopher and social critics themselves were rejecting modern science as epistemologically privileged, Indians who went around signing statements of scientific temper were dupes and fools. The gist of the 
argument was this: Post-positivist critics, among whom Herbert Marcuse, Paul Feyerabend and Thomas Kuhn came in for special mention, have al ready "proved" that science does not and cannot confront dogmas, because science needs dogmas (e.g., paradigms) in order to do its work [... ]. A society like India, on the periphery of the world, needed to protect itself from, rather than cultivate, the hegemony of science. ${ }^{3}$

There you have it, in a nutshell, the two types of critiques of science: internal to imperial knowledge (Feyerabend, etc.) and from dependency relations (herein the sphere of knowledge) created by the colonial difference. Herethequestion is then, how to get out of this dilemma.

Nanda's proposal starts from her conviction that such "cultural relativization of needs is challenged by Amartya Sen and Marta Nussbaum in their capabilities approach to human functioning" ${ }^{4}$. M ore specifically, $N$ anda explains,

\begin{abstract}
the capabilities ethics is based upon a critical universalism that holds a set of basic human capabilities as intrinsically worthwhile for flourishing human life, while admitting that these capabilities may be expressed differently in different cultures and different historical epochs. Amartya Sen holds that "personal interests and welfare are not just matters of perception; there are objective aspects of these concepts that command attention, even when the corresponding self-perception does not exist" (Sen). Two levels of human capabilities serveas the objective criteria for judging whether or not any society can be said to be developing or regressing. The first level sets the ground floor for a life that is suitable for humans as a species distinct from other animals and includes bodily capacities like avoiding hunger and thirst and includes the distinctively human traits like humor and play and the ability to reason and make moral judgments. The next level describes capabilities that make a human life a good life. These capabilities include, for instance, the ability to "imagine to think and to reason" and the ability for critical reflection and crucially for women, the ability to "live one's own life and nobody else's". (N ussbaum) ${ }^{5}$
\end{abstract}

Nanda begins the next paragraph with a disclaimer: "Contrary to Shiva and Mies, Nussbaum and Sen believe that it is both possible and desirable to move all people, everywhere above the threshold for a good life defined in terms of capabilities" 6 . Here we have the crux of the argument illustrated by the positions of Shiva and $N$ andy, in India, and Nussbaum and Sen in the U nited States. Who is in the "right" position to "move" people without the consent of people to be moved? Is the design to move Iraqi people to "democracy" possible and desirable? Geo-historical locations, in the modern/colonial world, go together with an entire subjectivity formation, with knowledge and skin (in Fanon's sense) within imperial countries as well as in their colonies or ex-colonies. Nanda's subjective formation, as she explains in the prologue, is shaped while following closely, both intellectually and emotionally, the debates over science in India and later in her life in the U nited States the postmodern critiques of science.

U pon reflection on both experiences, $\mathrm{N}$ anda sees in Sen and Nussbaum the argument that people should be moved above the threshold of a good life based on the universality of human capabilities. With all due respect for Sen and Nussbaum's wellargued opinion, why should one agree that what they believe would indeed be universally desirable and accepted by all human beings? Sen and Nussbaum's definition of human capabilities is clearly grounded in the instrumental concept of reason. Only a 
cosmology that operates on the principle of profit, production, and accumulation could make of human capabilities a basic universal principle. If you are a Black AfroCaribbean, and a critical mind likeSen and N ussbaum, you would not begin by making of human capabilities a universal principle, or say that humanity is defined, once and for all, by the detachment of men from nature. Certainly, that is very much grounded in European modernity, in political theory as well as in political economy-civilization as detachment from nature, economic production as exploitation of nature, and human beings as "free" entities to decide their lives independent of the politicaleconomic structure and the hegemonic system of values that establishes what constitutes a good life. A critical Afro-Caribbean mind (as critical as a white US feminist and an Indian economist who embraced liberal principles in both political theory and political economy), would certainly twist that principle in two directions ${ }^{7}$. The first would be to challenge the idea that human capabilities are universal and manifest themselves differently in different traditions, as the multicultural argument reproduced by $\mathrm{N}$ anda would have it. And the second is that the idea of humanity being defined by its detachment from nature doesn't bode well with the Black population, who themselves have been defined, in the modern/colonial world, by their proximity to nature and their inferior humanity.

The idea that humanity is universally defined by its separation from nature first emerged in seventeenth-century Europe and developed in tandem with the industrial revolution, as the appropriation of lands increased, accompanied by the increasing demand for natural resources. Even when Aristotle conceived human beings as "rational animals" he was not necessarily defining humanity in opposition, or in contradistinction, to nature. The entire Indigenous movement today, in the Americas and in Australasia conceives humanity, as they have always conceived it, on the basis of a different logic: nature is life, the energy that generates and maintains life and humanity is not different and separate from nature but an integral part of it. Within the scope of this short article, I can only state that these principles are accepted by indigenous men and women alike, as they know, based on their own experience, rationality, and creativity, that they want to live their own lives and not someone else's (not even Nussbaum's!). Of course not all white women in the United States and Europe reach the critical point of becoming aware of their rights; and, of course, not all indigenous women are slaves just because they are indigenous and women. Quite the contrary, there are many among them who do not need Nussbaum's and Sen's principles of capability to realize what rights and freedoms are. To believe that Nussbaum's and Sen's (with all due respect to their work) two basic principles (humans separated from nature and being all equals in their capabilities) are universally valid beyond the cosmology on which they are based, means to accept an imperial view of goodness. And it is only the imperial rationality, hidden under the rhetoric of happiness for all, that justifies N anda's support for N ussbaum's and Sen's position according to which they "believe that it is both possible and desirable to move all people, everywhere above the threshold for a good life defined in terms of capabilities". Once again, who decides what is a good life for whom? Who moves all people to goodness? 
II.

One of N anda's strong arguments against Shiva and $\mathrm{N}$ andy, and the Indian Left, is that their argument and critique of W estern science played into the hands of $\mathrm{H}$ indu N ationalism and its defense of Vedic Science. I would like to stress that Shiva and Nandy are not supporters of $\mathrm{H}$ indu Nationalism, but that their critique of Western imperialism runs parallel to Hindu Nationalists' critique of India's Westernization. One among many examples from $\mathrm{N}$ andy:

The literature of the ultra-Hindu nationalist group, for instance, is replete with exhortations to improve the Hindus socially, morally, and psychologically. This improvement is invariably defined according to the values thrown up by the experience of the " $\mathrm{Hindu}$ defeat" in the hands of the non-Hindus: hard discipline, masculinity, impulse control, power, and nationalism geared to realpolitick. Even when the authoritarian Indian takes a revivalist position, thereby trying to return to the uterine warmth of an idealized past and an idealized motherland, what he projects into the past and into the concept of the nation are nothing other than conventional W estern middle class values. ${ }^{8}$

As for Vandana Shiva onecould say that even if some of $\mathrm{N}$ anda's criticisms arejustified, Shiva cannot be reduced to her position in "eco-feminism". In other works such as The M onoculture of the M ind (1992) and Stolen Harvest: The Hijacking of the Global Food Supply (2000), Shiva has been consistently denouncing and revealing-based on the particular experienceof neo-liberalism in India-therhetoric of modernity under which the logic of coloniality continues to increasethenumbers of the "wretched of theearth", as Frantz Fanon had it. N ow let's assume that in spite of that (and not because of), some of N andy's and Shiva's arguments could play into the hands of $\mathrm{H}$ indu N ationalist arguments. If we choose that line of argumentation, it would be easy to show that some of N ussbaum'sand Sen'sargumentsaswell play rightinto thehands of $\mathrm{N}$ eo-liberal agendas.

What do I mean by $\mathrm{Neo-Liberalism?} \mathrm{Briefly,} \mathrm{the} \mathrm{ideas} \mathrm{that} \mathrm{the} \mathrm{market} \mathrm{should} \mathrm{be} \mathrm{the}$ point of reference for the organization of society and in order to value human capabilities trade unions should be eliminated and citizens' vital ity and social lives diminished to fit their function solely as human resources and labor providers. These are some of the principles of $\mathrm{Neo}$-liberal civilizing ideals. They presuppose precisely the universality of human capabilities. M ore specifically, some of the basic $\mathrm{Neo}$-liberal principles (that we can compare with those of Hindu N ationalism) are based on the rhetoric of modernity, which, in the sixteenth and seventeenth centuries, mainly consisted of conversion as salvation. Since the nineteenth century, salvation has been articulated ostensibly to benefit civilization and, increasingly, to further progress. Thus, according to the $\mathrm{Neo-}$ liberal creed, sustained economic growth is the best way to insure human progress. The question is: why should we assume that "progress", defined as such, is necessary for human happiness and the good life? The market in N eo-liberal global designs has to be free and function without interference from the State in order to insure that economic globalization be beneficial to everyone. Accordingly, governments should mainly function to provide the infrastructure to advance the rule of law with respect to property rights and contracts. In other words, and in the words that Nanda derives from Nussbaum and Sen, "it is both possible and desirable to move all people, everywhere above the threshold for a good life defined in terms of capabilities". Today it is N eo- 
liberalism that is the main agent moving people in and out of the service of globalization. Instead of "moving all people everywhere above the threshold for a good life", which is the rhetoric of modernity actualized by N eo-liberal principles, what we have, as Vandana Shiva argued ${ }^{9}$, are increasing war, increasing marginalization and poverty, increasing genocides in Africa, a return to totalitarian regimes forced by the brutal entry of $\mathrm{Neo}$-liberal religion of the market in Russia, and the increasing violence of the clash of civilizations announced by Samuel Huntington (1995). Thus, the question raised by $\mathrm{N}$ anda is relevant and not only for India. It is a question valid for the entire world as there is an increasing complicity (forced or voluntary) between $\mathrm{Neo}$-liberal agents in Europe and the United States and local supporters and defenders of $\mathrm{NeO}$ liberalism in the rest of the world. On the other hand, there are increasing mixed reactions and oppositions to the universal creed that progress lifts poverty and that war is necessary to generate freedom around the world. These "moves" move in two directions. On the one hand, religious fundamentalisms react to the impositions of market fundamentalism, and imperial State terrorism enacts the movement of people supported by the laws of the State (itself backed up by military forces). On the other hand, progressive intellectuals like Shiva, Nandy, N ussbaum, and Sen, as well as various social movements increasing in number - albeit with different agendas- can coordinate compatible moves and make "possible and desirable" production of other, alternative, fruitful dialogues. This should be possible once the pretense of a universal truth that is right and good for everyone, gives way to conception of pluri-versal needs and interests, political projects, and ethical commitment to creating a world in which many worlds could co-exist, rather than toward one world in which many worlds would sub-sist.

Of coursel havenot been implying that $\mathrm{N}$ ussbaum and Sen are $\mathrm{NeO}$-liberals; neither am I suggesting that Shiva and $\mathrm{N}$ andy are $\mathrm{H}$ indu N ationalists. Rather, what I am saying is that N ussbaum and Sen, on the one hand, and Shiva and Nandy on the other, may have complementary agendas between them as progressive intellectuals in different locales of the geo-political distribution of intellectual labor. All of them can be criticized on the grounds that their positions support either theuniversal totalitarian beliefs that ground. Neo-liberal agendas or the nativist totalitarian beliefs that hold up Hindu $N$ ationalist agendas. Thus, what I am trying to argue is that while Shiva and $\mathrm{N}$ andy are helpful in critiquing Neo-liberal principles under the feet of Nussbaum and Sen, Nussbaum and Sen are also helpful in that they can be used for critiquing the Hindu $\mathrm{N}$ ationalist principles under the feet of Shiva and $\mathrm{N}$ andy. A pluri-topical critique is of the essence if one wants to move away from the cage created by modern epistemology and the naturalization of invented dichotomies which have resulted in opposing fundamentalisms: theglobal fundamentalism of the market (i.e. N eo-liberal civilization) and the emergence of variegated religious fundamentalisms (Christian, Islamic, Hindu). Geo-historical locations and bio-graphical experiences are not taken here as multicultural manifestations of some universal principle but, on the contrary, as the geohistorical distribution of knowledge that the logic of coloniality enacted and naturalized. Colonization is a process that to be operative and effective needs to create the colonial difference in the domain of knowledge and in the domain of being: "I am not 
thinking, therefore I do not exist" is a formula of imperial designs instilled among the dominated population through universities, media, and all other forms of communication.

If a dialogue between multiple projects that are moving toward another gl obalization can take place in order to change the coloniality of knowledge and of being (something that scholars, intellectuals, activists, media people can do), it would be under the assumption that many peoplearound theworld (for example, Shiva and $\mathrm{N}$ andy in India, Shariati in Iran, Yasinnein M orocco, Dussel in Argentina, H araway and H ardy, Sen and N ussbaum in theU nited States, etc.) arequestioning scienceand $\mathrm{NeO}$-liberalism in light of their complicity with imperial global designs. Science cannot be measured and evaluated by theconceptual structure of scientific theories; nor by equating them with sacred beliefs (which was Feyerabend's and Kuhn's ground-breaking contribution), but by looking at the complicity between scientific research that ignores colonization, exploitation, and devaluation of life, both human and non-human (which is one of Shiva's contributions). In all thesecases, the common ground is the critique of modernity from the perspective of coloniality, a relentless critique of all forms of colonization of knowledge and being, including science since science became a colonizing tool that helps and furthers accumulation of capital at the expense of human lives, rather than being an apparatus that contests it. Can we really call it "progress" when five human beings' jobs are eliminated because there is now one machine that can do it all, and the society provides no job replacements for those who lost their means of subsistence? To claim universality for particular ideas as $\mathrm{N}$ anda does using N ussbaum and Sen, means to fall back into the assumption that there are certain abstract universals (liberal, Christian, M arxist, M uslim) that are better than others. And such claims, regardless of who makes them and from what geo-historical and bio-graphical location, haveal waysbeen theseed of a totalitarian destiny ${ }^{10}$.

Let's remember the two basic principles that $N$ anda derives from Sen and N ussbaum to judge whether a society is regressing or progressing:

Two levels of human capabilities serve as the objective criteria for judging whether or not any society can be said to be developing or regressing. The first level sets the ground floor for a life that is suitable for humans as a species distinct from other animals and includes bodily capacities like avoiding hunger and thirst and includes the distinctively human traits like humor and play and the ability to reason and make moral judgments. The next level describes capabilitiesthat make a human lifea good life. These capabilities include, for instance, the ability to "imagine, to think and to reason" and the ability for critical reflection and crucially for women, the ability to "live one's own life and nobody else's". ${ }^{11}$

First of all, what constitutes a good life and whether a society is developing or regressing are not only particular points of view, based on the criteria that humans distinguish themselves from nature but, above all, are also particular statements that do not pause to evaluate that their own particularity is being assumed as universal. If, at this point in history, one assumes criteria such as the one N anda derives from N ussbaum and Sen as universal, one is indeed regressing in the sense that it is assumed there is only one set of criteria that names the universal and establishes what is progress, what is stagnation, and what is a good life. 
Some of Nanda's criticisms of Shiva and M ies on eco-feminism arewell taken. In the case of Shiva, it would be necessary to distinguish from the rest, her sometimes excessive linking of earth and womanhood from whereshederives many of her conclusions. However, there are other criticisms that deserve more scrutiny because they reveal some of Nanda's assumptions that are not only different but mainly contrary to Shiva's. For example, N anda takes on Shiva's assumption that "subsistence economies were the 'original affluent societies", in the sense that subsistence economies took care of "basic vital needs of their members". The problem is, for $\mathrm{N}$ anda, that Shiva defines thenature of basic needs and the level at which they could be satisfied, by "cultural norms alone":

By so relativizing needs, Shiva is able to gloss over some grim facts behind her much-celebrated "affluence" of non-Western agricultural systems. The fact [is], for example, that subsistence economies did not (and still do not) supply all the nutritional needs of all their members at level that is biologically adequate for maintaining basic capabilities. ${ }^{12}$

$N$ anda counters such "cultural relativization of needs" with the challenges she finds in Amartya Sen and Martha Nussbaum in their "capabilities approach to human functioning". The "capabilities approach" is based on a tree-diagram that derives and spreads cultural differences from a uni-versal principle. Thus,

The capabilities ethics is based upon a "critical universalism" that holds a set of basic human capabilities as intrinsically worthwhilefor a flourishing human life, whileadmitting that these capabilities may be expressed differently in different cultures and different historical epochs. ${ }^{13}$

The logic of "critical universalism" is the logic that needs and sustains "multiculturalism". That is, multiculturalism is accepted as a matter of fact, on the assumption that there are some universal principles from which cultural differences emerge in various geographical locations and historical epochs. But, really, who can say, beyond God [ any God] or any group of human beings who pretends to take the place of God in a secular form, what "universal principles" are? My own position starts from the premises of an ethics based on critical cosmopolitanism; ${ }^{14}$ and critical cosmopolitanism begins with the recognition of the "epistemic colonial difference" against which Shiva and N andy have been struggling and continueto do so; while for Sen and N ussbaum the epistemic colonial difference is out of their sight; that is precisely what "critical universalism" means, blindness to the colonial difference and, consequently, the possibility of conceiving of critical cosmopolitanism to erase the colonial epistemic difference. But what does the epistemic colonial differencemean? I meansthat sincethesixteenth century until today, all knowledges that have not been cast in some of the modern European imperial languages (Italian, Spanish, and Portuguese, in the first wave of colonial expansion; French, English, and German in the second wave, since the eighteenth century), grounded in Greek and Latin, were not and are not sustainable knowledges. Therefore, even if onerecognizesthat sometimes Shiva or N andy run therisk of supporting dubious national ist positions, one shall not fail to recognizethat they arestruggling in theviolent epistemic borders created by the colonial epistemic difference, that is, what makes the essential differencein themodern/colonial world and what movesthesystem - thehegemonic concept of knowledge (e.g., political theory, political economy, expertise in 
agriculture and deforestation, in pharmaceutical products, etc.). On the other hand, Sen's and N ussbaum's blindness to the colonial epistemic difference (of which "critical universalism" is but aconsequence) putsthem at risk of supporting fundamentalist positions in power, today, under the name of $\mathrm{Neo}$-liberal philosophy and civilization for which "critical universalism" is far from being a challenge and even less a threat.

The question is that there is a geopolitical space of knowledge that Professor $\mathrm{N}$ anda overlooks in her re-setting of the dichotomy "modernity vs. nativism". That being said, I take her outstanding contribution to be the links she establishes between postmodern and feminist critiques of science, in the U nited States (H araway, H arding, etc.) and the matching of this critique with those enacted by $\mathrm{Hindu}$ nationalists. However, in between, there is the colonial epistemic difference that is overlooked. Or, if you do not want to reify it, let's say that in my vocabulary that colonial difference(s) and colonial differential(s) are instances of the same phenomenon that organizes the modern/colonial world. If modernity is left al one, without its constitutive dark side, coloniality, then there is no other alternative that conceives society and history in the linear time of progress. That is why, for $\mathrm{N}$ anda, the "prophets are looking backward" in which "back" (which is spatial) has the temporal connotations that "primitive" has, for example, acquired in the eighteenth century. If we bring coloniality into the picture and underline the simultaneity of histories around the world, then "modernity" and "nativism" are opposed contents of the samelogic: the logic of coloniality.

\section{III.}

There are two levels in $\mathrm{N}$ anda's argument that I have been playing out in my previous comments. One is the specific argument that relates post-modern critiques of science in the W est to the Indian Left and to H indu N ationalism. Theother is the moregeneral and more global, which links science and technology - willingly or not-to imperial global designs. A case in point is N orbert W iener, unquestionable leading figure in the emergence of the N ew Science for his contribution to "cybernetics" (the control of and communication in animals and machines). Two years after the publication of his seminal work, Wiener published a follow-up, The H uman U se of H uman Beings: Cybernetics and Society (1950) in which he denounced the use of science for the control, domination, and exploitation of human life rather than for improvement of it. Very familiar, indeed, nowadays-although W iener is not exactly a familiar name in the circuits of CN N , the N ew York Times, N ewsweek, Atlantic M onthly, or CBS. And the reason is that the defenders of the "marvels of science" (and not interested in talking about marginalization, exploitation, domination, colonization, dispensability of human life- in war or in pharmaceutical business) who recognized W iener as a mathematical genius while shutting him down as a critical thinker of capitalist society. One example of Wiener's defamation was the profile of him that his enemies were able to transform into an effective cliché. The defamation had him as a great mathematician but a little bit eccentric. When Wiener used to talk about society and the ethical responsibility of the scientific community-a topic that was beyond his "area of expertise" hecould not betaken seriously ${ }^{15}$. Which shows that the scientist could go one of two ways: either unconsciously 
support the dominant system (which for fivehundred years has been capital ism accompanied by a rhetoric of salvation, Christian as well as secular) or knowingly remain silent regarding the growing injustice, exploitation, colonization, etc., that the products of science are being used for. Sure, scientific advances in medicine save human lives, as one counterargument goes. Sure, but for each human life saved in the high-income brackets, hundreds if not thousands of lives are lost in the growing margins of capitalist economies and $90 \%$ percent of the planet's population is living in inhuman conditions. In summary, with all the advances of science, there is a silence about the "totality" of the system - the visible succesfful rhetoric of modernity and the invisible exploitative and inhuman logic of coloniality, which is essential to insure the "success" - that is, "growing progress and increasing poverty", to use the formula of US political economist, Henry George. In what follows I would like to push forward this general aspect implied in Nanda's critique, beyond the particular case she examines in India and its entanglement with theW est (basically, sincetheeighteenth century, England and in the shadows, Germany, France, and the U nited States).

AsI suggested before, the problem today is not $\mathrm{H}$ indu $\mathrm{N}$ ationalism against Christian and ( $\mathrm{NeO}$ ) Liberal fundamentalisms (and we could add Islamic), but how to imagine and practice critical theories, and how to engage in and advance ethical, epistemic, political, and economic projects that will help us "move" (together and not by some abstract design) to the terrain of critical cosmopolitanism and dialogical ethics. In this regard, Shiva and Nandy, on the one hand, and Sen and Nussbaum, on the other, should not be seen-or confronted-as mutual "enemies". One should not use one pair to chastise the other, but rather they should be seen as complementing each other in a pluri-versal global cause in which neither Sen and N ussbaum nor Shiva and N andy have the last word on how to establish a universal solution or to judge and plan the future of the world. If they did, critical universalism would be but a different form of fundamentalism, since thereis only one (uni) way, the only way. Sen's and N ussbaum's positions are as regional and provincial as Shiva's and Nandy's. The difference is that the former are piggybacking on the Western pretense of universality (in this particular case, the liberal version of it) whilethelatter arestruggling with the violence of imperial designs exported to India and all over the world. In other words, there are local histories that havethe privilege to invent and export global (imperial) designs, and thereare local histories that have to live with them. Sen and Nussbaum are located in the first space; Shiva and Nandy in the second.

What are the ways out? W ell, that will be and already is a collective enterprise in the making. I would like to propose epistemic delinking as the first step of a global move toward pluri-versality as a universal project-and this is where critical theory and decolonization will prevail over the results of sciences. The example of N orbert Wiener should remind us that the scientist's ethical and political concerns should have priority over his or her scientific contributions. But as W iener's adversaries demonstrate, those who use science unethically at the expense of the goodness of society in general, will keep on fighting to retain their privileges in England, India, the United States, Indonesia, etc. The question goes beyond U niversalism vs. $\mathrm{N}$ ativism. The question is to work toward epistemic delinking, that is, toward fracturing the naturalization of the two 
domains in which the system functions: on the one hand, the dominant rhetoric of modernity and alleged "universal" values and principles that reflect the perspective and the interests of those who, consciously or not, pronounce what "universal" values and principles are (which are culturally relative - principles and values, of democracy, of freedom, of science and technology), and, on the other hand, the opposing forces, which in the name of tradition (e.g. Vedic science) remains within the same logic of the system. H ence, neither Hindu Nationalism nor Islamic Fundamentalism nor, for that matter, Communism, are about delinking, and for different reasons that are relevant to my argument. Communism (and in spite of M arx's valuable critical analysis of the structure of industrial capitalism in the nineteenth century, in Europe) belongs to the same logic as Liberalism and Christianity. The fact that both Liberalism and Communism rejected Christianity should not make us forget that the rejection was in content and not in claiming the universality of different values (secular liberal and secular socialist/communist). Now, Hindu Nationalism and Islamic Fundamentalism interestingly enough are responses from different "religions", that is, non-Western Christian (Protestant and Catholic in all its variants, which means that Orthodox Christianity is considered non-W estern, as Samuel H untington clearly reminded all of us several years ago). However, although H induism and Islamism are religions that do not respond to the same logic as Christianity, Hindu Nationalism and Islamic Fundamentalism nevertheless havefallen into the "W estern trap" and have responded within the rules of the game imposed by theW est; that is, looking to defend and impose "their own abstract universals". They all oppose one another at the level of the rhetoric of modernity (e.g., the claim made by those left out of alternative modernities, peripheral modernities, subaltern modernities, etc.), as if modernity were an already established model or an unavoidable destination to attain. To fall into the trap of the rhetoric of modernity is to finally believe that you either have to have modernity, you have to be modern or you fall out of history. And W estern science is one of the measuring sticks and desirable goals. Science, in other words, is not only a necessity and a wonderful space for human creativity, but above all is a commodity desired by those who feel left out of or left behind by "modernity". And, by the same token, science is perceived by others as one of the power tools of the logic of coloniality. ${ }^{16}$

Thus "Western civilization, science, knowledge, etc.", has two sides, one visible and theother invisible. Thevisiblesideistheachievements and thepublic statementsreporting the results and triumphs of science. The invisible side is the constant war against other forms of knowledge produced in languages other than the six imperial ones and grounded in memories and knowledges alien to the West. And with knowledge goes political economy and ethics. "Western civilization, knowledge, science" is both a set of principles, beliefs, categories of thought, argumentative logics, etc., that produces knowledgeand understanding, and a set of rhetorical arguments used to justify progress, civilization, improvement of human life, that erases and denies other forms of knowledges and understanding and that dispenses with other human lives that become "the rest". Shiva and N andy havebeen operating at thecrux of theproduction and theerasure and denial of knowledge in India through thecolonial period and the process of nationstate building after 1947. N ussbaum and Sen are far removed from that struggle, from 
the violence of building a nation with the wounds of colonial legacies. Their struggle is within the oppressive aspects of Liberalism and within the Western tradition.

The first step for delinking would be, then, to recognize the regional positions (i.e. historical, sociological, institutional, race- and gender-based) in which both Shiva and $\mathrm{N}$ andy, on one hand, and Sen and N ussbaum, on the other, are thinking and arguing. To accomplish the first step it would be necessary to shift the geography and the biography of reason, and to operate on the principle that knowledge is geo- and biopolitically constituted. That is, geo-politics of knowledges derives from local experiences (as science derives from local experiences of Western capitalist countries) in which the geo-historical aspect accounts for the tension, negotiation, and violence in all theterrainstouched by Western colonial expansion; whilethebio-political accounts for the experiences, needs, angers, interests, and critical acumen of the "scientist" or critical intellectual who feels in her or his body the colonial matrix of power and translates it into conceptual analysis and arguments toward the decolonization of knowledge (that is, one of the fundamental components of the colonial matrix of power). Feminist epistemology countering the patriarchal foundation of knowledge goes handin-hand with "the color of reason" as Nigerian philosopher Emmanuelle Chuckwudi Eze labelled the racist underpinning of I mmanuel Kant's universal ism. ${ }^{17}$

Consequently, instead of assuming that knowledge and reason derive from the dictates of God, the sovereignty of the Ego (knowing subject) or the pure rationality of Organization, as the N ew Sciences have it, in which the organization of knowledge and theknowledge of organization setting a new stage in which "organization and complexity" takes over N ewton's "law of nature" and establishes a new epistemic model, geo and bio-political locations assume the local histories (marked by the epistemic colonial difference) of the knowing subject, local histories that have been denied by the defenders of the universality of Western science and philosophy. Today, instead, both in Europe and the United States, the epistemic colonial difference is no longer "down there" but "up here"; a reality that makes more visible the universal blindness of $N$ anda's critiqueand her endorsement of N ussbaum' and Sen's "critical universal ism".

In the previous paragraph I outlined the conditions for epistemic delinking. How to move forward, to the next step. Once again, this is a collective enterprise but, fortunately, it is not necessary to invent the steps because some are al ready in place and they continue to grow all around the world. Let me give you some examples. N andy's and Shiva's work have at least two faces, one that $\mathrm{N}$ anda sees at risk of supporting $\mathrm{H}$ indu Nationalism and the other moving toward epistemic delinking; that is, in opening up spaces of knowledgethat are not caught in the four visible meta-narratives of European modernity: Christianity in its Catholic and Protestant versions; Secular Conservatism (linked to Christianity), Liberalism, and Socialism/M arxism and their corresponding "neo" versions- the latter two being explicitly against Christianity.

Sen and Nussbaum are located within the variegated versions of Liberal metanarratives, and their valuable critique is crucial within those limits. It would be naïve to believe that their critiques have to be revealing and illuminating for progressive Indians and $\mathrm{M}$ uslim intellectuals and activists. One could say that Sen would be as relevant to $\mathrm{N}$ andy or to M ohammed Al-Jabri as N andy and Al-Jabri would beto Sen; examples 
could be found also for the case of Nussbaum. Shiva and Nandy emerge from their experiences and locations at the crossroads (or epistemic border) between the colonial matrix of power operating in India since late eighteenth century and the silenced memories and categories of knowledge that the colonial matrix of power (by British officers and intellectuals as well as by the complicit Indian elite) attempted to erase. H owever, as Ranahit Guha would say, "There was one Indian battle that Britain never won. It was a battle for the appropriation of Indian past. It began with the East India Company's accession to diwani in $1765 "{ }^{\prime 18}$

People are proud of declaring themselves Christians, Liberals or Socialists/M arxists. No one, or just a few (with reluctance or sometimes lightly), would declare themselves proud of being imperialists/colonialists. But of course, colonialists have been and are Christians, Conservatives, Liberals, and Socialists/M arxists, which, of course, doesn't mean that every Christian, Liberal, Socialist/M arxist is a colonialist. What it means is that, in the last analysis, Christianity, Secular Conservatism, Liberalism and Socialism/ $\mathrm{M}$ arxism (as well as Islamism or Hinduism), are not a warranty of anything and, there fore, liberating projects could emerge from any of them (one within Liberalism is illustrated by Nussbaum and Sen); but totalitarian and fundamentalist projects can also emerge from the same ideologies, as history tells us. History has plenty of examples of Christian, Liberal, and M arxist totalitarianism, as well of course of totalitarian regimes grounded in Islamic ideas (which doesn't mean, once again, that Islamism and fundamentalism are oneand thesame). By the sametoken, $\mathrm{H}$ indu N ationalism doesn't mean that fundamentalism is the only road you can go if you declare yourself a $\mathrm{Hindu}$.

If colonialism is the invisible companion of any of the modern meta-narratives (if colonial ity goes together with modernity), thereis still a wholeand entire world beyond the totalizing effect of the four modern meta-narratives and their ideological and invisible companion. And that enormous epistemic space that imperial/colonial expansion silenced and continues to silence or ignore-justified in the rhetoric of democracy, freedom, modernization, development and what have you-the space of repressed epistemologies which, today, offers to individuals and communities whose subjectivity has been formed in the borders and in the tension of the epistemic colonial difference, the distinctive possibility of delinking. The fact that $\mathrm{H}$ indu N ationalism made its case by rejecting W estern and promoting Vedic science doesn't mean that this is the only way to argue from a $\mathrm{H}$ indu position: the domain of knowledge that could begenerated by re-investing Vedic epistemic principles, doesn't have to be justified in terms of the rules of the game imposed by the West, and doesn't have to fall into the trap of having to affirm that there is a V edic science preferableto W estern science. The challenge, and the threat, is first to argue from Vedic epistemological perspective, that the concept of science articulated in European modernity is fine and good, but that its universal claim does not correspond to the law of the cosmos! Furthermore, if you reject N ewtonian physics and replace it by the non-teleological view of chaos theory and "the new sciences", still, the view of the cosmos that emerges from it is far from corresponding one to one with the cosmos itself. It is a view built on a "tradition", the modern-European tradition that began with Copernicus's breakthrough and followed by Galileo. Vedic and Islamic knowledges- as well as Indigenous knowledges in the Americas and 
Australasia - are today in the process of being reinvested all around the world. But of course, none of these knowledges, and none of the original languages in which these knowledges are embedded, can survive by themselves. Re-investing Vedic or Indigenous knowledges, today, means to do it in dialogue (sometimes friendly, sometimes confrontational) with W estern categories of thought (remember: grounded in Greek or Latin languages and translated into the three modern languages of "serious knowledge" - French, German, and English). Re-investing means also to changethe perspective (to change it and not to invert it). Changing but not inverting perspectives brings as a consequence border epistemology, an epistemology of the border from the perspective of what has been denied and the possibility of conceptual delinking. Border epistemology is a powerful one for the simple reason that it is based, on the one hand, on the critical examination of non-W estern languages and traditions and, on the other, on the critical examination of Western languages and traditions. Border epistemology presupposes a double critique (of Shiva and N ussbaum, for example, as well as N andy and Sen), a double critique that can transcend the modern/colonial structure and contribute to move all toward a trans-modern world. At that point, "critical cosmopolitanism" can only be predicated on pluri-versality (and not on uni-versality). Pluriversality as a universal project would help in uncoupling the concepts and structures of scientific discourses from the unintended consequences of scientific discoveries at the service of escalating wars (like the war against terrorism) and escalating genocides because, for example, making a profit with pharmaceutical products is more important, for those who control it, than saving human lives.

The last comment I would like to make- derived from the previous paragraphs-is that because science, old and new, has always stopped short when it comes to examining domination, oppression, subordination, exploitation, etc., critical theory now becomes the unavoidable road to follow for those who are not ready yet to surrender to the imperial consequences of the myth of sciences and of scientific practices. Critical theory has been associated with Karl M arx's unveiling of the logic of capital, although as always, "critical takes" (if not theory in the contemporary sense of the expression) on the initial moments of Western expansion and the foundation of capitalism as we know it today, can be found in the sixteenth and seventeenth centuries. At that point, Indigenous people from the Americas and African slaves did not have the "conceptual tools" available to Marx after one hundred years of political economy (e.g., Adam Smith) grounded on the colonial experience of the Spanish empires and the British Caribbean plantations, before moving to India. Be as it may, Marx and then Max Horkheimer are two anchors when it comes to critical theory. For EnriqueDussel (one of thefounders of Philosophy of Liberation, in Latin America), the critical contribution of $M$ arx consisted in taking the principles and the logic of modern social sciences and using them to unveil and reveal the hidden logic of capital, that is, the logic of exploitation hidden under the rhetoric of progress. ${ }^{19}$ Horkheimer, following the same path, called traditional all theory that operates on the basic assumptions of the empirical sciences; traditional are theories that give a new sense to factual information beyond their descriptive nature. Critical theory, instead, explores and reveals the hidden principles and domineering and exploitative consequences of knowledge (Horkheimer, 
1937). Today, as the examples from India deployed in $\mathrm{N}$ anda's well-informed study show, critical theory cannot remain within the confines of the industrial exploitation of the proletariat in Europe, which were the experiences upon which Marx and H orkheimer (sensitive to domination and control due to their Jewish social upbringing) based their critical theory. Critical theory, today, is and will bea decolonizing enterprise (decolonization of knowledge), even in the cases of industrial exploitation in the colonies, in the ex-third world or in today's emerging economies and countries whose populations are living with one dollar a day. Racism goes hand-in-hand with the exploitation, both in the ex-colonies and increasingly in Europe and the U nited States due to the massive immigration from the ex-third world.

In this context, the scenario presented to us by Professor Nanda changes its configuration. The question is not only that postmodern critique of science, in the W est, and leftist critique of sciences in India (in Africa, the M iddle East, or Latin America), can help the cause of non-W estern fundamental isms; thefact isthat humanisticidealsbased on liberal premises in the West can also play into the hand of neo-liberal political and economic theory. That is, they could play into the hands of Western fundamentalisms advanced in the name of freedom and democracy. Briefly, there is no safe place within abstract uni-versals of European modernity or its counterpart, $\mathrm{H}$ indu Nationalism or Islamic fundamentalism. The way out is conceptual delinking, the relentless practice of double critique, of critical theory as epistemic decolonization and of border epistemology to avoid thetrap of fundamentalisms in reverse. Theroad toward thefutureis about learning to conceiveand enact critical cosmopolitan practices, decolonizing knowledge, and thinking beyond the rules of modern thought. Pluri-versality as a universal project shall not bethought out as a new abstract universal but as a connector, a placeof encounter and exchange of liberating and decolonizing practices, where it would make sense to fight for the idea that an other world is possible; and that world will be conceived as a world in which many worlds can co-exist (as the Zapatistas would have it). Ruled out will be both any attempt to appropriate pluri-versality in order to convert it to a commodity and any temptation to build a powerful army around to eliminateall of those who hate pluri-versality and want to destroy it! Pluri-versality as a universal project is being conceived as a global dialogue and action to eliminate all vestiges of totalitarian thinking, thelogic of coloniality, thedispensability of human lives and theconcentration of money and meaning in fewer and fewer hands. In that world, Nussbaum and Sen, on the one hand, and Shiva and Nandy, on the other, should be able to work together against W estern and Eastern totalitarian projects and fundamental beliefs.

\section{Notes}

[1] MeeraN anda, ProphetsFacingBackward: Postmodern Critiques of Scienceand $\mathrm{H}$ indu $\mathrm{N}$ ationalism in India (New Brunswick, NJ: Rutgers U niversity Press, 2003).

[2] "Biographically motivated" is here a positive observation and not a critique. The position I am taking in my commentary argues in favor of the bio-graphical inscription in the production of knowledge, which has been suppressed by modern Ego-politics of knowledge behind modern and European concept of "scientific knowledge"; the absence of the bio-graphic gave scientific knowledge the magic touch of universality. 
[3] Ashis Nandy, quoted in Nanda, Prophets Facing Backward, p. 211.

[4] Nanda, Prophets Facing Backward, p. 231.

[5] I bid., bolds mine, italics Nanda's.

[6] I bid., bolds mine, italics Nanda's.

[7] See for instance, Lewis Gordon, "Fanon and Development: A Philosophical Look" in Africa Development/D evelopment Afrique, XXIX, 1, 2004, 65-88; and "African American Philosophy, Race and the Geography of reason" in N ot only the M asters tools: African American Studies in Theory and Practice. Lewis Gordon, ed. Boulder: CO Paradigm Publisher, 2005, forthcoming.

[8] "Adorno in India. Revisiting the Psychology of Fascism" in Exiled at Home (Delhi: Oxford University Press, 1998), pp. 104-5, italics mine.

[9] See Vandana Shiva, "Globalization and Its Fall Out", http://www.zmag.org/sustainers/ content/2003-04/02shiva.cfm

[10] Richard Robbins, Global Problems and the Culture of Capitalism (Allyn and Bacon, 1999); see also Susan George, "A brief history of neoliberalism", http://www.globalexchange.org/ campaigns/econ101/neoliberalism.html

[11] Nanda, ProphetsFacing Backward, p. 231. Italicsmine, last sentencequotation from N ussbaum.

[12] Ibid.

[13] Ibid.

[14] "The many faces of cosmopolis: Border thinking and critical cosmopolitanism", Public Culture 12.3, 2000.

[15] Steve H eims, John Von N euman, and N orbert W iener, From M athematics to the Technologies of Life and Death (Cambridge, M A: M IT Press, 1980).

[16] Distinguished Mexican sociologist Pablo Gonzáles Casanova, has recently published a detailed and critical analysis of the imperial dimensions and uses of the $\mathrm{N}$ ew Sciences and the need to activate critical analysis and decolonizing projects in the Humanities to unveil the dangers hidden under the marvel ous achievements of the N ew Sciences. Las N uevas Ciencias y Ias Humanidades. De la Academia a la Politica (Barcelona: Anthropos, 2004).

[17] Emmanuel Chukwudi Eze, "The color of reason: The idea of "race" in Kant's anthropology", in Chucwudi Eze, ed., Postcolonial African Philosophy: A Critical Reader (London: Blackwell, 1997), pp. 103-40.

[18] Ranajit Guha, Dominance Without H egemony, quoted in Walter D. M ignolo, "Coloniality of Power and Subalternity", in Ileana Rodriguez, ed., The Latin American Subaltern Studies Reader (Durham: Duke University Press, 2001), pp. 424-45.

[19] Enrique Dussel, "El programa científico de investigaci'on de Karl M arx" in H acia una filosofía política crítica (Sevilla: Palimpsesto, 2001), pp. 279-303.

\section{References}

Dussel, Enrique. 2001. "El programa científico de investigación de Karl M arx". In H acia una filosoíia política crítica Sevilla: Palimpesto, 279-303.

Eze, Emmaunel Chukwudi, 1997. "The Color of Reason: The Idea of 'Race in Kant's Anthropology". In Emmanuel Chukwudi Eze, ed. Postocolonial African Philosophy. A Critical Reader. London: Blackwell, 103-140.

George, Susan. 1999. "A Brief History of Neo-liberalism." http://www.globalpolicy.org/globaliz/ econ/histneol.htm;

González Casanova, Pablo. 2004. Las nuevas ciencias y las humanidades. De la academia a la política. Barcelona: Anthropos.

Guha, Ranajit. 2001. Dominance Without Hegemony, quoted in Walter D. Mignolo "Coloniality of Power and Subalternity". In Ileana Rodriguez, editor. The Latin American Subaltern Studies Reader. Durham: Duke University Press, 424-445. 
Heims, Steve, Neuman, J. Von \& Wiener, N. 1980 From M athematics to the Technologies of Life and Death. Cambridge: MIT.

M ignolo, Walter D. 2000. "The M any Faces of Cosmo-polis: Border Thinking and Critical Cosmopolitanism." Public Culture, 12 3, 721-748.

$\mathrm{N}$ anda, M eera. 2003. Prophets Facin Backward: Postmodern Critiques of Science and $\mathrm{H}$ indu N ationalism in India. Rutgers: Rutgers University Press.

Nandi, Ashis. 1998. "Adorno in India. Revisiting the Psychology of Fascism." In Exiled at Home. Delhi: Oxford U niversity Press, 99-111.

Robbins, Richard. 1999. Global Problems and the Culture of Capitalism. London: Allyn and Bacon.

Shiva, Vandana. 2003-4. "Globalization and Its Fall." http://www.zmag.org/sustainers/content/ 2003-04/02shiva.cfm 